\title{
ЛИТЕРАТУРОВЕДЕНИЕ
}

УДК $82.0+930.27+908$

DOI: $10.17223 / 19986645 / 45 / 11$

\section{В.А. Есипова}

\section{ЧИТАТЕЛЬСКИЕ ПРАКТИКИ И РЕЦЕПЦИЯ ТЕКСТА: ТОМСКИЙ ЧИНОВНИК ХІХ В. А.М. ГОРОХОВ И ЕГО НАСТАВЛЕНИЕ ДЕТЯМ ${ }^{1}$}

\begin{abstract}
Статья посвящена рассмотрению рукописи «Залог, или Нравственное зериало», написанной томским чиновником А.М. Гороховым в 30-е г2. ХІХ в. Текст рукописи представляет собой наставление Горохова детям; он ранее не публиковался и хранится 8 виде автографа в фонде ОРКП НБ ТГУ. Выявлены источники, которыми пользовался Горохов, методы его работы с текстом. Показано, что рукопись позволяет реконструировать круг чтения томского чиновника, его литературные интересы, представления о книге и чтении.

Ключевые слова: история литературы, рукописи, Сибирь, А.М. Горохов.
\end{abstract}

Неотъемлемой частью реконструкции литературного процесса в Сибири является анализ существовавших в регионе читательских практик. Этот аспект трудно поддается анализу в первую очередь в связи с отсутствием достаточного массива источников для исследования читательской рецепции как отдельных произведений, так и литературного процесса в целом. Действительно, любой литературный текст адресован прежде всего читателю. За читательским откликом можно следить по рецензиям в литературных журналах, эпистолярным и мемуарным источникам, но это зачастую документы, вышедшие из столичной образованной среды, близкой к литературным кругам. Для исследования провинциального читателя данных не так много; в какойто мере их можно извлечь из рукописных сборников и журналов, бытовавших в провинции, в том числе и в Сибири, в XVIII - начале XX в. При этом именно в провинции присутствовал тот самый «массовый читатель», который составлял основу круга подписчиков «толстых» журналов, а следовательно, и экономическую основу существования многих отечественных литераторов. Однако восприятие этим «массовым читателем» явлений современного ему литературного процесса изучено крайне мало.

В этой связи привлекает внимание рукопись томского чиновника А.М. Горохова «Залог, или Нравственное зерцало», хранящаяся в отделе рукописей и книжных памятников Научной библиотеки Томского государственного университета (ОРКП НБ ТГУ) [1]. Она была написана в 30-е гг. XIX в. в Томске и представляет собой наставление Горохова его детям; текст

\footnotetext{
${ }^{1}$ Исследование выполнено при поддержке РГНФ и Администрации Томской области в рамках научного проекта №16-14-70001 (a/p).
} 
не предназначался автором к публикации. Истории рукописи и биографии ее автора был посвящен ряд публикаций В.П. Бойко $[2,3]$.

Автор текста - Александр Михайлович Горохов - родился в 1769 г. в Петербурге. Он занимал разные административные должности в Иркутске, Бийске, Каинске, Енисейске, Нарыме и Томске. Завершил службу в 1820-х гг. в Томске в должности советника и чиновника особых поручений, дослужившись до 8-го класса согласно Табели о рангах. В Томске хорошо известен один из его сыновей - Философ Александрович Горохов, «Томский герцог», один из самых состоятельных людей Сибири, история быстрого восхождения и стремительного падения которого неоднократно публиковалась (см.: [4. С. $140,177-180,188-189 ; 5]$ и др.).

Рукопись носит авторское заглавие - «Залог, или Нравственное зеркало», указывающее на предметы, которые могут служить руководством в жизни...». Она представляет собой обширный блок на 274 листах, форматом в $2^{0}$ (фолио). Автор пронумеровал листы в первой и второй части рукописи отдельно (8 нн., 2 - 154, 2 нн., 1 - 100). Рукопись написана преимущественно на бумаге производства Вятских фабрик, что характерно для Сибири XIX в. Весь текст написан одним и тем же почерком: это беглая, крупная скоропись XIX в., с отдельными элементами XVIII в.

Украшение рукописи весьма скромно. Поля на всех листах прочерчены чернилами. На титульном листе, под заголовком, вклеена небольшая круглая иллюстрация, явно вырезанная из книги. Это гравюра на меди, в круглой линейной рамке, она раскрашена от руки цветными карандашами и представляет собой пейзаж с изображением реки, лодки и гуляющих людей. На л. 60 об. наклеено изображение собаки, вырезанное из желтой фольги. Вероятно, аналогичное по технике исполнения изображение бабочки имело место также на л. 170 об., однако в настоящее время оно утрачено, и предположить, что там было помещено, можно лишь по следам клея и краски.

Основа крышек полукожаного переплета - самодельный картон, склеенный из фрагментов делопроизводственных документов XVIII в., сверху крышки оклеены зеленой бумагой. Уголки и корешок коричневой кожи, на корешке - слепое тиснение. Также на корешке имеется ярлык из красной бумаги, на котором рукой Горохова написано «Зерцало». На верхней крышке также наклеен ярлык из розовой бумаги, вырезанный в форме сердечка; на нем А.М. Горохов написал: «Зерцало или...» (далее текст затерт).

Особо следует сказать о записях и пометах на полях и форзацах рукописи; они позволяют восстановить ее историю. Прежде всего, следует обратить внимание на печать, черный оттиск которой имеется на л. 272 об. На печати изображен гербовый щит, разделенный диагональной полосой, направленной в левый верхний угол; на полосе затерта, но все же читается фамилия «Горохов». Изображения в правом верхнем и левом нижнем углах щита не просматриваются, поскольку плохо пропечатаны. Щит увенчан дворянским шлемом, над которым помещено изображение льва с пальмовой ветвью в лапах, развернутого влево. По сторонам щита пышный намет, а под щитом расположены изображения двух орденов на лентах (крестообразного и круглого). Известно, что Горохов являлся кавалером ордена Владимира 4-й степени; знак этого ордена имел как раз крестообразную форму. Орден Владимира 
4-й степени вручался лицам, имевшим не ниже 7-го класса в табели о рангах (надворный советник, подполковник, капитан второго ранга), а также им награждались за 35 -летнюю беспорочную службу ${ }^{1}$. Что касается второго орденского знака, также на ленте, но имеющего круглую форму, пока не удалось установить, что это за орденский знак.

Интересно, что герб целым рядом деталей напоминает герб дворян Тарховых, описание которого помещено в Общем гербовнике дворянских родов [8. С. 72-73]. На гербе Тарховых есть некоторые детали, которые не просматриваются на печати в рукописи Горохова; кроме того, на нем, разумеется, отсутствует надпись «Горохов» на ленте, протянутой поперек щита. Вместе с тем типологическое сходство гербов позволяет предполагать возможное родство Горохова с семьей Тарховых - не исключено, что по женской линии. Однако в настоящий момент недостаточно материалов, чтобы полностью подтвердить или опровергнуть это предположение. Отметим также, что на л. 274 об. имеется рисунок, выполненный пером от руки и в общих чертах воспроизводящий печать с л. 272 об. Рисунок печати воспроизведен крайне приблизительно, но в центре изображения довольно отчетливо видна надпись «A. Горох...».

На ряде листов читаются писцовые записи, извещающие о ходе работ. Из них становится ясно, что Горохов создавал «Зерцало» как минимум в два этапа. Так, на л. 166 об. читаем: «Набело переписывать это начал июня с 10 числа, кончил июля 5-го дня 1837 года в Томске. К сему следует еще особое прибавление и здесь же, № 3»; на л. 272 об.: «Было кончено июня 27-го дня 1839 года. А далее еще прибавки». Многочисленные дополнения к тексту сделаны Гороховым как на полях или между строк, так и на вклеенных листах (л. 3, 10 об., 15, 15 об., 21 об., 29, 37 об., 43 об., 44, 49 об. и мн. др.).

Горохов обсуждал написанное и передавал рукопись для прочтения авторитетным, с его точки зрения, людям. Об этом имеются свидетельства: так, на л. 1 об. читается письменный отзыв о рукописи Агапита, первого епископа Томского и Енисейского; в левом верхнем углу А. Гороховым помечено: «К нему представил 5 августа, а он обратился 10 сентября 1839 года». Агапит написал, в числе прочего, следующее: «...благонамеренный и усиленный труд попечительнейшего отца о детях нельзя было не прочесть, и притом не без особенного к тому внимания».

В тексте рукописи и на полях имеются также многочисленные карандашные пометы и комментарии к тексту, выполненные рукой еп. Агапита. Часть дополнений к тексту была сделана Гороховым в ответ на пожелания епископа. Например, на л. 72 Агапит поддерживает рассуждения автора о морали праведников репликой «Достойно замечания». На л. 110, когда Горохов высказывает мнение, что «должна быть признана лучшею та книга, которая

\footnotetext{
${ }^{1}$ «Ст. 386. Императорский орден св. равноапостольного князя Владимира установлен в награду подвигов, совершаемых на поприще государственной службы, и в воздаяние трудов, для пользы общественной подъемлемых. Ст. 387. Орден св. Владимира разделяется на 4 степени, из коих две первые именуются степенями большого креста.... Четвертая степень. Крест такой же, но меньшей величины; носится в петлице на ленте шириной в полвершка. На кресте, жалуемом за тридцатипятилетнюю службу, на поперечных концах с обеих сторон серебряная надпись: 35 лет. [6. Ст. 386, 387]. См. также [7].
} 
представляет истину под приятными формами», что это «зеркало, в которое мы смотримся, часто не видя себя». Епископ Агапит с ним не согласен: «Не так - надобно иначе думать - друг мой». А.М. Горохову были дороги замечания епископа; он даже составил их полный перечень и подклеил его к форзацу рукописи (л. I).

Также на л. 274 об. на нижнем поле читается: «С особенным удовольствием прочитал. Протоиерей Созонт Куртуков». Созонт Иванович Куртуков (1775-1834?) являлся священником в церквях Барнаула и Тюмени; установлен факт его знакомства с таким известным духовным лицом, как Макарий (Глухарев) $[9 ; 10 . \text { С. } 11]^{1}$. Очевидно, мнение Созонта Куртукова было важным для А.М. Горохова.

О том, каким образом рукопись оказалась в фонде НБ ТГУ, позволяют судить оттиски печатей, имеющиеся на форзаце; это печать Томского этнолого-археологического музея ТГУ от 1924 г. за №108; там же печать музея истории материальной культуры ТГУ от 28 декабря 1948 г. за № 50. Известно, что книги из Музея истории материальной культуры ТГУ были переданы в НБ 26 мая 1954 г. [11. Л. 1-5], среди них была и представительная коллекция рукописей и кириллических изданий из собрания Тобольского церковного древлехранилища. Рукопись Горохова не несет на себе следов пребывания в Тобольском древлехранилище; остается предположить, что уже в 1920-е гг. она была кем-то передана в университет, однако детали этого процесса в настоящий момент неизвестны. Первичное описание рукописи и нумерацию листов выполнила первая заведующая ОРКП НБ ТГУ Л.А. Панова.

Особенность текста рукописи заключается в обилии явных и скрытых цитат и ссылок на литературные и фольклорные произведения, которые были знакомы А.М. Горохову; цитаты он использовал для обоснования своих взглядов. Так, он упоминает, что «когда-то давным-давно читывал стародавние истории и так называемые небылицы в лицах: о Бове королевиче, о Петре златых ключах, о царе Кучуме, Царь-девице, о Яге бабе и тому подобные смышлености и замысловатости» (л. 213). Также он упоминает, что пробует «играть на скрипке или напевать дрожащим голосом старинные были и духовные песни» (л. 34 об.). К сожалению, других деталей о своем знакомстве с этими текстами Горохов не приводит, поэтому судить о нем можно лишь поверхностно, констатируя сам факт такого знакомства.

Особое место среди источников, привлекавшихся А.М. Гороховым, занимает Библия, включая книги как Ветхого, так и Нового Завета. Автор часто ссылается на нее и делает обширные выписки из Посланий апостольских, Книги премудростей Соломона, Книги премудростей Иисуса, сына Сирахова и др. Так, из Пятикнижия Моисеева (Бытие, Исход, Левит, Числа и Второзаконие) Горохов использует две книги: Исход и Второзаконие. Из книги Второзакония им приводится прямая цитата (л. 54-54 об.); она служит для обоснования мотивов написания «Зерцала»: «Да помянеши весь путь, им же проведе тебе Господь Бог твой...». Текст из книги Исход пересказывается (л. 151, вставка на полях) - это известный сюжет о явлении ангела Моисею в

${ }^{1}$ В 1830 г. С.И. Куртуков - барнаульский соборный протоиерей, в 1830 г. он встречался там с о. Макарием (Глухаревым), направлявшимся из Тобольска в Алтайскую духовную миссию. 
горящем терновом кусте. Из остальных ветхозаветных книг по одному разу цитируются Псалтырь (л. 178, псалом 144) и первая книга Царств (л. 177 об. 178). Дважды обращается Горохов к тексту книги Екклезиаста (л. 54 об., 56), причем во втором случае он ошибочно указывает, что известная цитата «все видимое есть суета» и что «ничего нового нет, было прежде, есть ныне и будет впредь, ибо род минет и род приходит, вся словеса о сем трудны, и не может никто глаголати» взята из книги премудрости Соломона. Неоднократно обращается Горохов к тексту книги Иисуса, сына Сирахова: это небольшие цитаты (л. 40, 69 об., 79, 95 об.), а также две довольно обширные серии выписок (л. 144 и 155 об. - 156 об.). В последнем случае это подборка выписок на очень интересующую Горохова тему: взаимоотношения в семье вообще и между родителями и детьми в частности («Делом и словом чти отца твоего, да найдет ти благословение от него», «Всем сердцем твоим прослави отца твоего, и матерни болезни не забуди», «Дщи мудра почтет отца своего, а несрамлящаяся печаль отцу», «Гнев велик - жена пьянива, и студа ея не имать покрыти» и др.). Также активно Горохов использовал текст книги Притчей Соломоновых (л. 69, 140, 144, 163 об.). На л. 154 об. - 155 об. читается целая серия выписок из этого текста, также посвященная вопросам семейных взаимоотношений («Слушай, сыне, отца Твоего наказание (учения), да мудр будеши на последок твой», «Злословий отца или матерь, угашает светильник свой, зеницама же очию своею узрит тьму, и напоследок не благословится» и др.), а также о грехе пьянства («Невинно вино, проклято есть пьянство», «Не буди винопийца, всяк бо пьяница и любодей обнищают» и др.). К книге Премудростей Соломона Горохов обращался реже: цитаты из нее встречаются только одни раз, вместе с комплексом выписок из книги Притчей Соломоновых (л. 144-145).

Книги Нового Завета Горохов использует не так активно. В тексте имеются цитаты из трех (из известных четырех) канонических Евангелий: две небольшие цитаты из Евангелия от Матфея (л. 56,127$)$ и одна цитата из Евангелия от Марка (л. 56). Несколько больше цитат из Евангелия от Луки (л. 124 об., 125 об., 151 об.), а также пересказ известной притчи о талантах, зарытых в землю (л. 4-5). Послания апостольские также привлекали внимание Горохова весьма фрагментарно: он использует исключительно послания апостола Павла. Так, в рукописи цитируются послание к римлянам (л. 124 об., 151 об.), к филиппийцам (л. 136), к галатам (л. 140), к фессалоникийцам (л. 200) и к ефесянам (л. 200). Необходимо отметить, что во всех случаях это не цитаты непосредственно в тексте, а выписки на вклейках, позже добавленных к рукописи. Возможно, Горохов обратился к тексту Посланий апостола Павла уже после того, как основной текст был закончен, и подбирал дополнительную аргументацию своей точки зрения.

Текст рукописи позволяет оценить знакомство А.М. Горохова с русской и зарубежной литературой. Так, Горохову были известны произведения русских поэтов XVIII в. Г.Р. Державина («Духовные оды» и др.) и А.Д. Кантемиpa (Сатира I). Например, рассуждая о том, что случается множество «бедствий и зол, которые обыкновенно бывают следствием дурного употребления богатства, дарованного нам слепым случаем» (л. 43 об.), Горохов вспоминает и цитирует стихотворение Державина «К первому соседу» (Горохов ссылает- 
ся на него как на «стишок Державина, сказанный Голикову»). В рукописи приводится лишь фрагмент стихотворения:

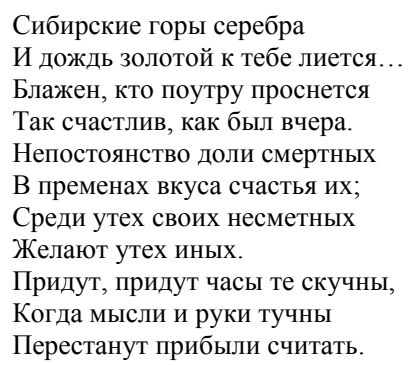

Отметим, что при первой публикации в «Санкт-Петербургском вестнике» [12. С. 108] произведение появилось под заглавием «Ода к моему соседу господину $\mathrm{N} »$; заглавие «К первому соседу» появилось в более поздних публикациях. Стихотворение обращено к курскому купцу М.С. Голикову, одно время проживавшему в Сибири и являвшемуся одним из соучредителей компании, позже получившей название Русско-Американской, вместе с И. Шелеховым и И.Л. Голиковым.

Также Горохов цитирует стихотворение Державина «Видение мурзы» (л. 59 об. - 60), впервые опубликованное в «Московском журнале» [13. С. 8]:

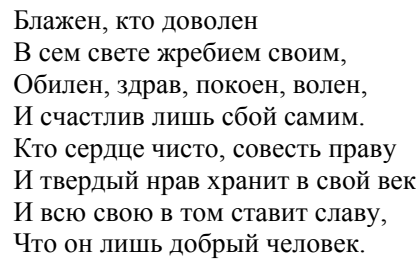

Отметим, что пояснения Державина, фактически данные им в этом стихотворении по поводу обвинений его в лести императрице в связи с одой «Фелице», отказ его от мысли стать «советником при троне» (в отличие от прозаического плана стихотворения «Видение мурзы», составленного в 1783 г.) и изложенные в этой связи взгляды на жизнь довольно близки тому, что проповедует Горохов. Как и Державин, Горохов не являлся политическим бойцом, но высоко ставил гражданское служение отечеству и личную честность и искренность.

Очень важен для Горохова мотив равнодушия к богатству материальному - в противовес богатству духовному. Аргументируя свою позицию, он приводит цитаты еще из двух произведений Державина: стихотворения «Фелице» (л. 122 об.):

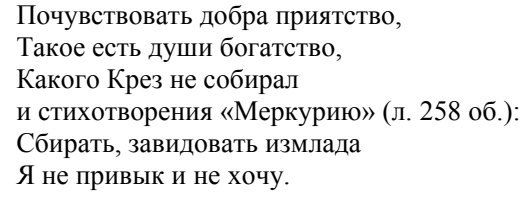


Богатство ль старику награда?

Давно с презреньем я топчу

Его всю прелесть равнодушно.

Как известно, последнее стихотворение появилось, когда в 1794 г. Державин был назначен президентом коммерц-коллегии против его желания.

Рекомендуя детям «не сходить со стези истины и уклоняться от несправедливости», Горохов демонстрирует знакомство с драматическими произведениями Державина. В качестве негативного примера, которому не следует подражать, им приводится краткая комическая цитата из песни Торопа из «Добрыни», произведения, которое сам Державин называл «театральным представлением с музыкой» (л. 89):

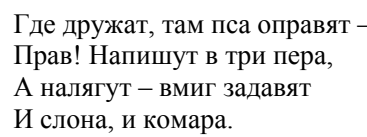

Произведение А.Д. Кантемира Горохов цитирует только один раз; он приводит фрагмент «Сатиры I», причем перефразированный (л. 212 об.):

\author{
Рукопись \\ Ум недозрелый, плод небольшой науки, \\ Покойся, не понуждай к перу мои руки, \\ Не писав, летящи дни века проводит, \\ Можно и славу достать, хоть творцом не \\ слыть. \\ Ведут к ней нетрудные в наш век пути многих, \\ На которых смелые не запнутся ноги. \\ Смотри! Смеются, кто в трудах над столом \\ гнется, \\ И уверяют, что, пяля в книгу глаза большого \\ уваженья не добьется.
}

\author{
Публикация [14. С. 57] \\ Ум недозрелый, плод недолгой науки, \\ Покойся, не понуждай к перу мои руки: \\ Не писав, летящи дни века проводити \\ Можно и славу достать, хоть творцом не слыти. \\ Ведут к ней нетрудные в наш век пути многи, \\ На которых смелые не запнутся ноги. \\ Всех неприятнее тот, что босы проклали \\ Девять сестер. Многи на нем силу потеряли, \\ Не дошед; нужно на нем потеть и учиться, \\ И в тех трудах всяк тебя как мору чужится, \\ Смеется, гнушается. Кто над столом гнется, \\ Пяля в книгу глаза, больших не добьется.
}

Басни И.А. Крылова используются Гороховым при подборе положительных примеров для детей. Так, он цитирует басню «Старик и трое молодых» (л. $18-18$ об.):

\author{
Из детства я к трудам привык, \\ А если от того, что делать начинаю, \\ Не мне лишь одному я пользы ожидаю, \\ То признаюсь, за труд такой еще \\ Охотнее берусь.
}

Той же цели служат и цитаты из басен «Ворона и лисица» (л. 90 об., вставка на полях): «...сколько раз твердили миру, что лесть гнусна, вредна. Но только все не впрок, и в сердце льстец всегда отыщет уголок»; а также «Две бочки» (л. 59 об.): «Кто про свое дело кричит всем без умолку - в том, верно, мало толку».

Однако был знаком Горохов и с произведениями Крылова, относящимися к совершенно другому жанру. Так, он перефразирует «Подражание псалму 
17-му» (л. 133), говоря о невозможности познать божество человеческим разумом:

Рукопись

Довольно с нас, чтоб Бога знать любить, То знает, что без него не может быть.
Публикация [15. С. 263]

Чтоб бога знать, быть должно богом; Но чтоб любить и чтить его,

Довольно сердца одного

Тема страстей и грехов человеческих чрезвычайно волновала Горохова; он неоднократно обращается к ней, увещевая детей не поддаваться им. В качестве аргумента он использует, в числе прочего, творчество П. Сумарокова. Так, рассуждая о тщеславии и гордости, Горохов ссылается на оду «К человеку» (л. 96 об. - 97):

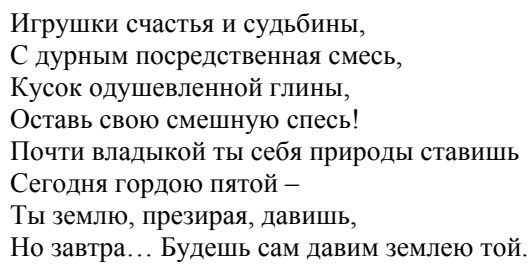

Однако Горохов не только цитирует произведения П.П. Сумарокова, но и сочиняет собственные тексты «по их мотивам». Так, в рукописи читается аллюзия на одну из эпиграмм Сумарокова (л. 159 об.):

Рукопись

Какой-то писака славную поэму сочинил, И всех читателей этим прослезил, Но я вам в 5 пуд сочиненья сбрякал! Но от него один лишь сам я и плакал.
Публикация [16. С. 151]

Битобе славную поэму сочинил. И всех читателей он ею прослезил. А ты, Глупонов, нам в пять пуд поэму сбрякал,

Но от твоей один лишь только цензор плакал.

Таким образом Горохов иронизирует над своим «Залогом», имея в виду его изрядный объем и одновременно выражая скрытое опасения о том, что дети так и не соберутся дочитать до конца этот обширный труд.

Но надежда быть понятым все же оказалась сильнее; снова обращаясь к детям, Горохов все же выражает уверенность, что родные ознакомятся с его текстом, что сделает более приятным конец его жизни. В качестве аргумента он приводит цитату из И.М. Долгорукова: «Вы не поверите, что я даже наизусть затвердил стих Долгорукова» (л. 42-42 об.). В данном случае имеется в виду стихотворение «Ответ на приветствие В. С...п», которое приводится Гороховым фрагментарно, но очень близко к тексту:

$$
\text { Рукопись }
$$

$\mathbf{A x}$, природа возвещает,

Скоро мне заснуть пора

Предтечу в гости посылает,

Стучится старость у двора!
Публикация [17. С. 146]

Но, ах! Природа возвещает,

Что скоро мне заснуть пора,

Предтечу в гости посылает,

Стучится старость у двора

В ответ на замечания - видимо, довольно частые - о том, что родственники Горохова (а именно сын Филолог) обладали существенным богатством, 
Горохов также приводит очень близко к тексту выдержку из стихотворения Долгорукова «Мой театр» (л. 59):

\begin{tabular}{ll}
\multicolumn{1}{c}{ Рукопись } & \multicolumn{1}{c}{ Публикация [17. С. 103] } \\
Меня поносят, слышу, строго, & Меня поносят, слышу, строго, \\
Зачем сижу я дома и тешу я себя. & Зачем так тешу я себя; \\
Кричат: он видно нажил много, & Кричат: он видно нажил много, \\
И честь, и совесть погубя! & И честь, и совесть погубя! \\
Прошу покорно всех нахалов - & Прошу покорно всех нахалов \\
Мой дом прийти ревизовать, & Мой дом прийти ревизовать, \\
Моих завидных капиталов & Моих завидных капиталов \\
Наличность осязать. & Наличнсть мягку осязать!.. \\
И, сделав обыск самый верный, & И сделав обыск самый верный, \\
Увидеть ясно без очков, & Увидят ясно без очков, \\
Что мой достаток беспримерный - & Что мой достаток беспримерный \\
Нарост на языке лжецов. & Нарост на языке лжецов.
\end{tabular}

Пренебрежение к богатству и материальному благополучию также иллюстрируется Гороховым цитатой из «Камина в Москве» Долгорукова (л. 30 об.): «Коль сыт одним - на что три блюда? Коль кафтан - на что их пять? К чему потребна денег груда? Умрешь - с собой ведь не взять...».

Религиозность Горохова уже была показана выше на примерах цитирования им книг Ветхого и Нового Завета. Однако привлекала его внимание и поэзия, содержащая соответствующие мотивы. Так, в рукописи есть две обширные цитаты из стихотворения В.И. Соколовского «Мироздание» (л. 133 вклеенный лист и л. 200):

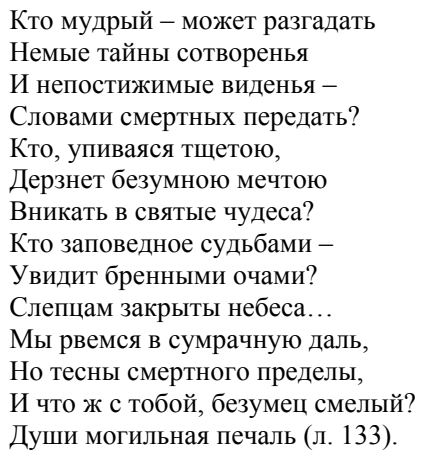

$\quad$ Рукопись (л. 200)
Затеплим святостью сердца,
Увлажним души мы слезами,
И благодарными мольбами -
Испросим милость у отца:
Пусть дух бессмертного провиденья,
Нам будет кормчим в море бед,
И Богу вновь дадим обет
Любви и веры, и смиренья!

Большое место в рукописи занимает проблема старения и смерти. Подводя жизненный итог, Горохов указывает детям на бренность всего сущего, ничтожность человека перед лицом Бога. Для иллюстрации он использует по- 
эму В.И. Соколовского «Хеверь», которую достаточно близко к тексту цитирует (л. 197 об.):

\begin{tabular}{ll}
\multicolumn{1}{c}{ Рукопись } & \multicolumn{1}{c}{ Публикация [19. С. 44-45] } \\
Века идут, проходят поколенья, & Века идут, преходят поколенья \\
Шумящие народные семьи - & Шумящие народные семьи \\
Скрываются и тонут в забытьи, & Скрываются и тонут в забытьи, \\
И новое особое мненье. & И новые, особенные мненья \\
В свою чреду приносит каждый век; & В свою чреду приносит каждый век, \\
И с каждым днем меняет человек - & И с каждым днем меняет человек \\
Все выводы, свои соображенья, & Все выводы своих соображений, \\
И то, что он сегодня счел благим, & И то, что он сегодня счел благим, \\
То завтра же, как басня перед ним, & То завтра же, как басня перед ним, \\
Но чувства? - они без измененья. & Но чувства, друг, - они без изменений.
\end{tabular}

Отношения родителей и детей - еще одна очень важная для Горохова тема. Вероятно, в наибольшей степени его волновала судьба сына Философа скорее всего, именно ему адресованы пассажи о бренности материального богатства. Вряд ли сын очень уж прислушивался к отцу, что вызывало непонимание между ними. В тексте «Залога» содержатся прямые призывы взять в качестве образца его, Александра Горохова, правильную жизнь и спокойную старость; в одном из таких случаев приводится цитата из «Горя от ума» А.С. Грибоедова (л. 44 об.):

\begin{tabular}{ll}
\multicolumn{1}{c}{ Рукопись } & \multicolumn{1}{c}{ Публикация [20. С. 13] } \\
На сей раз не надо детям образца, & Не надобно иного образца, \\
Когда в глазах пример отца. & Когда в глазах пример отца. \\
Смотрите на него, не хвастает сложеньем & Смотри ты на меня: не хвастаю сложеньем, \\
Однако был бодр, свеж и дожил до седин, & Однако бодр и свеж, и дожил до седин, \\
Свободен ныне и себе он господин, & Свободен, вдов, себе я господин... \\
Скромным известен поведеньем. & Монашеским известен поведеньем!
\end{tabular}

Неточности в цитировании в данном случае могут быть объяснены не только цитированием по памяти или необходимостью преобразовать текст под конкретные жизненные обстоятельства, которые представлялись важными Горохову (например, замена в последней строке «монашеским» на «скромным»). Пока трудно в точности установить, использовал ли Горохов публикацию «Горя от ума» или один из многочисленных списков, которые были в ходу в первой трети XIX в., поэтому ряд разночтений может быть объяснен особенностями имевшегося в его распоряжении списка.

«Зерцало» содержит также и ряд практических рекомендаций детям о поведении в свете. Горохов придает большое значение умению вести беседу, к месту пошутить. Признает он назидательную роль сатиры, которая «приносит иногда пользу более всякого нравоучения», и подкрепляет свою мысль цитатой из «Евгения Онегина»:

(л. 91, вклейка, фрагмент главы 6):

Приятно дерзкой эпиграммой

Взбесить оплошного врага,

Приятно зреть, как он упрямо,

Склонив бодливые рога,

Невольно в зеркало глядится

И узнавать себя стыдится. 
С точки зрения Горохова, способность обращаться в свете включает и умение общаться с самыми разными людьми, даже в том случае, если взгляды их совершенно противоположны. Для описания подобных отношений он приводит две строки из главы 2 (л. 215 об.):

Они сошлись - вода и камень,

Стихи и проза, лед и пламень ...

Предостерегает Горохов своих детей и от ложной дружбы, которая часто встречается в свете; для ее характеристики он использует стихотворение А.С. Пушкина «Дружба» (л. 71):

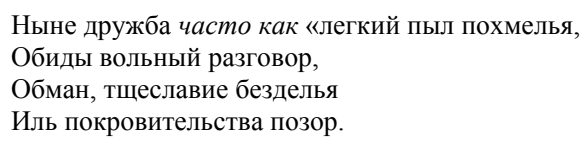

Важным для автора «Залога» была также способность с достоинством принимать любые испытания, поскольку «нередко и самое несчастие обращается в нашу пользу»; здесь ему пригодилось стихотворение В.Л. Пушкина «К лире» (л. 100):

\begin{tabular}{ll}
\multicolumn{1}{c}{ Рукопись } & \multicolumn{1}{c}{ Публикация [22. С. 657] } \\
К пользе и несчастие дает & Но к пользе и несчастье \\
Нам Бог терпеть; & Дает нам рок терпеть; \\
Когда пройдет ненастье - & Когда пройдет ненастье, \\
Приятней солнце зреть. & Приятней солнце зреть.
\end{tabular}

Существенное место в системе ценностей Горохова занимают взаимоотношения супругов. Для убедительности он вновь обращается к отрицательным примерам, которые черпает из главы 4 «Евгения Онегина» (л. 81-81 об.):

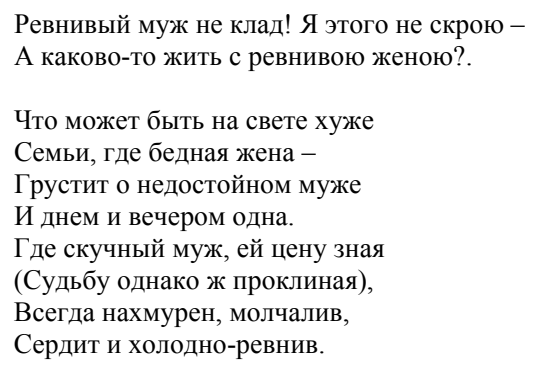

Горохов неоднократно сетует на свою многословность, неумение передать словами накопленный богатый опыт. Он готов «вывернуть свою голову, как походную сумку, наизнанку, чтоб вытряхнуть из нее разом все, что хранится в ней запасом о знании света и о замечаниях моих. Да невозможно, к тому же мне Пушкина подстрекает ум: пиши» (л. 174 об., вклейка): 
Рукопись

ы своих дум,

Останься тверд, спокоен и угрюм.

Признательность всегда за подвиг благородный!

А награда в самом тебе, ты сам свой высший суд,

Всех строже оценишь свой труд!
Публикация [21. С. 3]

Поэт! Не дорожи любовию народной. Восторженных похвал пройдет минутный шум; Услышишь суд глупца и смех толпы холодной, Но ты останься тверд, спокоен и угрюм.

Ты царь: живи один. Дорогою свободной Иди, куда влечет тебя свободный ум, Усовершенствуя плоды любимых дум, Не требуя наград за подвиг благородный. Они в самом тебе. Ты сам свой высший суд; Всех строже оценить умеешь ты свой труд. Ты им доволен ли, взыскательный художник? Доволен? Так пускай толпа его бранит И плюет на алтарь, где твой огонь горит, И в детской резвости колеблет твой треножник.

Таким образом, гражданский пафос стихотворения «Поэту» оказывается при цитировании практически нивелирован: Горохов воспринимает этот текст лишь как призыв продолжать свой труд, адресованный исключительно детям.

Возможно, что Горохов был знаком и с «Маленькими трагедиями» Пушкина: на л. 195, говоря о различных грехах, он описывает и грех скупости; этот фрагмент перекликается с текстом «Скупого рыцаря»: «Взгляните на скупца: он умирает от жажды изобильного источника, ибо скупые застрахованы от всех других страстей. Любовь к золоту преобладает над всеми его чувствами, слово «издержки» возмущает его душу, раздирает его сердце на тысячу частей, и только о милых своих денежках говорит он с умилением, оставшись наедине со своей скупостью».

Что касается творчества М.Ю. Лермонтова, то фрагменты перефразированного стихотворения «В альбом (из Байрона)» помещены Гороховым на титульный лист его рукописи и могут быть рассмотрены как своеобразный эпиграф ко всему тексту «Залога» в целом:

\begin{tabular}{ll}
\multicolumn{1}{c}{ Рукопись } & \multicolumn{1}{c}{ Публикация [23. С. 81] } \\
Как одинокая гробница & Как одинокая гробница \\
Вниманье путника зовет, & Вниманье путника зовет, \\
Так эта бедная страница & Так эта бедная страница \\
Пусть милый взор ваш привлечет & Пусть милый взор твой привлечет. \\
& \\
И если, после многих лет, & И если после многих лет, \\
Прочтете вы, как мечтал не поэт, & Прочтешь ты, как мечтал поэт, \\
И вспомните, как вас любил он, & И вспомнишь, как тебя любил он, \\
То вспомните, что его уж нет, & То думай, что его уж нет, \\
Что сердце здесь свое похоронил он. & Что сердце здесь похоронил он.
\end{tabular}

Эта цитата указывает на хорошее знакомство А.М. Горохова с современной ему литературой, так как вольный перевод стихотворения Байрона был опубликован практически одновременно с началом работы Горохова над его записками.

Продолжая тему переводов, отметим немного перефразированный фрагмент перевода из монолога Фауста, опубликованного в пушкинском «Современнике» (л. 181 об.): 


\begin{tabular}{ll}
\multicolumn{1}{c}{ Рукопись } & \multicolumn{1}{c}{ Публикация [24. С. 301] } \\
Жертвовать мечтам & Поверь мне, жертвовать мечтами \\
Своей выгодой смешно и безрассудно. & Своею выгодой смешно и безрассудно. \\
И, чтоб в науке счастья не подражать глупцам, & В науке счастья не подражай глупцам; \\
Рассудку, здравому постичь его нетрудно: & Рассудку здравому постичь ее не трудно, \\
За славой не гонись, не трать напрасных слов, & За славой не гонись, не трать напрасных слов, \\
Но к делу будь всегда готов. & Но к делу будь всегда готов.
\end{tabular}

Горохов цитирует стихи многих поэтов первой трети XIX в.: Е.Н. Шаховой (л. I), И. Клюшникова (л. 6), В.И. Красова (л. 6), И. Козлова (л. 47), А.А. Бестужева-Марлинского (л. 82 об., вклейка), Е.А. Баратынского (л. 86 об.), Георгия Задонского (л. 100 об., вклейка), Н.В. Кукольника (л. 182), Ф.Н. Глинки (л. 189 об.), Л.А. Якубовича (л. 212 об.), А.В. Тимофеева (л. 234 об.), К.М. Айбулата (л. 259), Ф.Н. Слепушкина (л. 259 об.), Э.И. Губеpa (л. 264). Отметим, что пока не все цитаты в рукописи Горохова идентифицированы, так что этот список может пополниться. Кроме того, часть текстов сочинена им самостоятельно, например посвящение жене (л. 273-274).

Что касается литературной критики, в рукописи неоднократно приводится мнение Ф.В. Булгарина (л. 11 об., 67 об., 71 об., 74, 89). Горохов во многом солидарен с ним: и в вопросе об оценке современного читателя, «покупающего книги понаслышке», и по поводу современной молодежи, позволяющей себе «думать немного, но говорить обо всем», и о различии между талантом рассказчика и талантом писателя.

Знакомство А.М. Горохова с зарубежной литературой, насколько об этом позволяет судить текст «Залога», менее обширно. Однако при этом присутствуют некоторые знаковые имена, которые обязан был знать любой образованный человек того времени. Например, в связи с рассуждением о важности веры в Бога упоминания удостоился «языческий писатель Плутарх, опровергающий лживые доводы сластолюбца Эпикура» (л. 249 об.). В этой же связи Горохов ссылается на Сократа и Пифагора (л. 140 об., вклейка), приводя характеристики Бога как верховного существа. Говоря о роли супружества в жизни человека, он цитирует анонимного «греческого мудреца» (л. 85) и «римские законы» (л. 85об.), где предлагается личное имение каждого из супругов почитать общим.

Упоминается в рукописи также «старинный трубадур Рюдель» (л. 174). Рюдель, Джауфре, сеньор де Блаи - провансальский трубадур, (ок. 1100 после 1148), участник второго крестового похода. Он известен тем, что сложил ряд прекрасных песен в честь графини Годьерны Триполитанской, о которой узнал со слов паломников. Чтобы встретиться с предметом своей любви, Рюдель отправился в Триполи, где и скончался на руках графини. Она повелела похоронить его с почестями, а сама постриглась в монашки. До наших дней дошло всего семь стихотворений Рюделя, четыре из них с нотами. Легенда о любви Рюделя и графини Триполитанской была очень популярна в европейской литературе XIX-XX вв. Этот сюжет лег в основу поэтической драмы Э. Ростана «Далекая принцесса», на этот же сюжет М. Врубелем создано мозаичное панно на фасаде московской гостиницы «Метрополь» и т.д. Интересно, что Горохов уподобляет себя Рюделю в первых строках третьей части «Зерцала», начатой им почти через год после окончания предыдущей 
части рукописи; это уподобление он объясняет тем, что «Он опять принялся за свое». Таким образом, в этом образе отклик со стороны Горохова нашла не лирическая составляющая истории, а лишь упорство Рюделя в достижении поставленной цели.

Если говорить об авторах Нового времени, упоминается Ж.Ж. Руссо (л. 174, вставка): Горохов сетует, что не может, «подобно Руссо... переливать чувств своих в мысли, а мысли в красноречие». Цитат из произведений Руссо при этом в рукописи нет.

Резюмируя, можно, сказать, что Горохов был весьма неплохо знаком с отечественной литературой XVIII - первой трети XIX в., преимущественно с поэтическими текстами. Однако проза привлекала с его стороны меньшее внимание, как и зарубежная литература, за исключением отдельных античных и средневековых авторов. Возможно, причина кроется в незнании Гороховым иностранных языков; но при этом отметим, что не особенно часто цитирует он и переводы. В целом его знакомство с зарубежной литературой основано, вероятнее всего, на классической гимназической программе, русскую же литературу он действительно любил и знал.

Отметим, что не все свои умозаключения Горохов подкреплял цитатами. В первую очередь к таким темам относится все глубоко личное: так, практически не содержится цитат в его автобиографическом рассказе в начале рукописи; отсутствуют цитаты и в его лирическом обращении к жене, которое располагается в конце «Залога».

Привлекают внимание методы работы А.М. Горохова с текстом. Он крайне редко воспроизводит текст стихотворений полностью; наиболее часто встречается комбинация из стихотворных фрагментов, извлеченных из различных произведений. Например, на л. 263 об. - 264 об. помещена обширная подборка, включающая фрагмент стихотворения Э.И. Губера «На кладбище», текст стихотворения Л.А. Якубовича «За днями дни текут» и еще три не идентифицированных пока стихотворных фрагмента. В рукописи все они составляют единый текстовый массив:

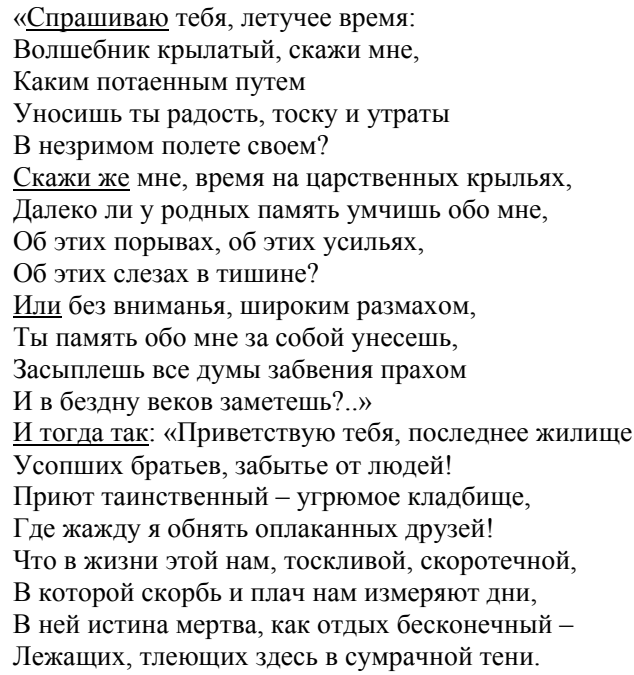


Скоро, скоро и я, друзья, без горьких слез прощанья,

Расстанусь навсегда с обителью живых!

Я лишний на земле... что мне в стране изгнанья?

В ней найдешь немного и друзей прямых».

И хотя «Тих и темен бедный дом,

Но в нем усну я долгим сном.

Гроб не выдаст мертвеца -

Не отдаст моих костей -

В посмеяние людей» $[25 . \text { С. 53 }]^{1}$.

«Жизнь наша бойка и скор ее полет

Имя - звук оставит только

Но и тот, увы, от времени замрет».

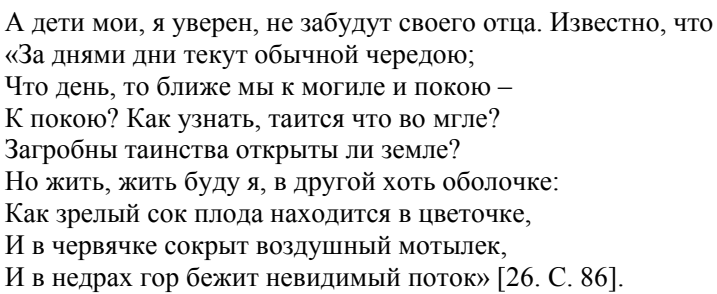

Эта подборка приведена почти в самом конце рукописи; здесь Горохов задается вопросом о природе творчества, о причинах, побуждающих человека «сочинять и составлять что-нибудь целое». Он не оценивает себя высоко как сочинителя, а причины составления такого обширного текста видит в том, что хотел «излить свои чувства на память детям», «и потому, чтобы быть занятым».

Яркий пример еще одной компиляции представляет титульный лист рукописи, который содержит фрагменты из стихотворения М.Ю. Лермонтова (разобранные выше), а также стихотворения Е.И. Шаховой. Отдельных слов заслуживает последний пример. Получается, что Горохову потребовалось «адаптировать» женские стихи, с чем он несколько неуклюже, но все же справился. Сравним с оригиналом:

Рукопись

Непрочной славы суета

Меня не льстит очарованьем,

Не жду вниманья от чужих людей,

Но я писал с упованьем,

Чтоб на устах родных, о книге моей

Улыбку сорвать одобренья,

И за успехи похожего на вдохновенье -

Внимать души их привет;

Как будто и я был поэт
Публикация [27. С. 117]

Непрочной славы суета

Меня не льстит очарованьем,

Не жду вниманья от людей,

Но я писала с упованьем,

Чтоб на устах родной моей

Улыбку видеть одобренья,

И за успехи вдохновенья

Внимать души ее привет;

Я дочь ей... я для ней поэт!

\footnotetext{
${ }^{1}$ В оригинале:
}

Тих и темен бедный дом;

В нем усну я долгим сном:

Гроб не выдаст мертвеца

В руки праздного глупца,

Не отдаст моих костей

$\mathrm{B}$ посмеяние людей. 
Как видно, Горохов комбинирует, соединяет между собой фрагменты текстов разных авторов, а порой добавляет к ним и свои собственные поэтические опыты. Несмотря на то, что в рукописи неоднократно говорится о том, что Горохов не считает себя сочинителем, видимо, его все же волновала тема творчества и сочинительства, а стихотворение Шаховой показалось ему подходящим, чтобы «примерить» на себя образ поэта.

И в компиляциях, и в единичных цитатах упоминания имен авторов встречаются далеко не всегда. Горохов указывает на авторство преимущественно в случае, когда приводит небольшую цитату или фразу (так, он ссылается на Г.Р. Державина, А.С. Пушкина, А.С. Грибоедова); в случае же обширной цитаты или комбинации цитат указание на автора, как правило, отсутствует. Не исключено, что составление компиляции он понимал как своеобразный творческий акт, а потому считал себя в какой-то мере и ее автором. Не следует исключать и возможность того, что он просто не помнил имен поэтов, строки которых приводил, или же просто не считал нужным их указание в рукописи, цель которой была заявлена как исключительно приватное поучение для детей.

Вероятнее всего, Горохов использовал для цитирования книги или журналы, имевшиеся у него под рукой. Действительно, в некоторых случаях кажется, что переделать текст таким образом, как в приведенном только что примере со стихотворением Шаховой, можно лишь имея текст публикации перед глазами. Однако нельзя исключать и цитирования по памяти; выше была уже приведена цитата, где Горохов сам говорит о том, что стихи Долгорукова он заучил наизусть.

Также рукопись Горохова позволяет установить, в какие сроки вновь вышедшие произведения поступали в Томск. Существует мнение, что в XIX в., до строительства железной дороги, имели место трудности с доставкой книг и журналов в отдаленные регионы Российской империи; это считается одним из факторов оторванности Сибири от общерусского литературного процесса. Однако рукопись Горохова позволяет если не опровергнуть это мнение, то поставить вопрос о том, насколько велики были эти сроки в действительности. Так, судя по записи самого Горохова, первую часть «Залога» он закончил в июне 1837 г., а переписал набело 5 июля 1937 г. Вторая часть была начата 22 декабря 1837 г., а окончена 27 июля 1839 г. Во второй части, среди прочего, цитируется апрельский номер (№4) пушкинского «Современника» за 1838 г. (в частности, стихотворение Л.А. Якубовича «За днями дни текут»). Таким образом, можно заключить, что временной промежуток между публикацией журнала и его прочтением в Томске составлял порядка года. При этом необходимо учитывать, что за это время журнал был доставлен в Томск, Горохов его прочел и поместил цитату из него в свою рукопись, т.е. фактический срок получения журнала был еще меньше.

В тексте рукописи Горохова есть также размышления о книгах и чтении. Так, в самом начале он оговаривает, что помещает в рукопись «все то, что на опыте испытал, видел, думал, или из начитки книг понимал» (л. 3). Обширный фрагмент, содержащий похвалу книге, содержится на л. 109 об. - 110; автор говорит о том, что «никакое другое удовольствие в жизни не может быть так питательно для всех вкусов, как чтение». Лучшей книгой он считает 
ту, «которая представляет истину под приятными формами», что это «зеркало, в которое мы смотримся, часто не видя себя». Горохов сравнивает книги с «прелестными существами». Вот фрагмент из его похвалы книге: «Признаюсь, что я и сам возвышаюсь духом, когда читаю священные книги, любуюсь красотою языка церковного, мало нам доступного. Но люблю и светские сочинения, соединяющие в себе чистую нравственность с прелестью воображения и красотою слога. В свете весьма часто друзья с переменой счастья, вместо утешения, умножают скорбь сердечную, удаляясь от того, кого обольщали личиной дружбы. Книги же остаются с нами и в дни скорбные, они служат к услаждению скучных часов. Истинно, что чтение книг, служа невинной забавой и для любителей свет, отводят от игры, распутства, от клеветы от суетных забот честолюбия... Но читать наскоро хорошую книгу есть то же, что проехать на почтовых лошадях через город, богатый дарами природы и произведениями искусства: ум не получит никакой пользы ни от того, ни от другого» (л. 110 об. - 111).

Вместе с тем он категорически против того, чтобы чтением занималась женщина, тем более - «без разбора» (л. 110). Позволим себе обширную цитату: «Но чего добивается читающая женщина? Ума? Спаси, Господи, люди твоя, в том числе меня, раба твоего, от начитанного ума женского! Это ад для природного здравого рассудка! Сердце! Сердце! Вот лучший женский ум! Как сказала одна из них: читающая женщина уже более не женщина, это профессор в чепце, семинарист в желтой шали. Для чего она читает? Чтобы подавать свое мнение? И вот она спорит, переспоривает, горячится, шумит, визжит! ... Одним словом, нет пощады от начитанной женщины. Она говорит о всем и всегда, она все читала, все знает. Не найдете в ней вы только малого незнания, которое так быстро сближает образованного мужчину с женщиной».

С точки зрения Горохова, неправа и молодежь, полагающаяся только на чтение книг и не слушающаяся советов старших (л. 207 об. - 208): «И это именно оттого, что многие из них все знания свои почерпают из книг и воображают, что прочитав их несколько, они сделались умнее отцов своих! И очень редко, разве которые учатся собственными опытами, умеют ценить лета и почитать старость».

Не вызывают доверия у Горохова анонимные «современные романы», которые «действуют не столько на ум, сколько на воображение» (л. 241), а лучшей книгой он считает священное писание, которое является «источником всех утешений» (л. 240 об.). Образ книги часто используется Гороховым для сравнения: так, людей в свете он уподобляет «книгам в шкафах за стеклом в богатом переплете, где видим одно их заглавие» (л. 71), а сам свет характеризует как «живую книгу - книгу пеструю, занимательную, но не всякому дается ее мудреная грамота» (л. 220 об.).

Таким образом, рукопись А.М. Горохова представляет безусловный интерес для исследования читательских предпочтений, литературных вкусов, методов работы с текстом томского чиновника XIX в., современника пушкинской эпохи. В результате первичного анализа этого текста Горохов предстает перед нами как человек глубоко консервативного склада, основанного на христианской морали, что обусловлено не в последнюю очередь его пре- 
клонным возрастом. Он хорошо знаком с отечественной литературой времен своей юности - и в то же время не все литературные новинки понимает и принимает, выделяя ряд авторов, в том числе широко известных и в настоящее время. Несмотря на обилие цитат в тексте, имеются темы, которые Горохов предпочитает освещать от первого лица; это в основном личные воспоминания или переживания. Цитирование применяется в качестве аргументации в попытке убедить детей «жить правильно»; цитаты используются в качестве как положительных, так и отрицательных примеров. В тематике этих цитат отражаются основные системообразующие проблемы, структурирующие мировоззрение Горохова: пренебрежение земными благами в противовес обращению к божественному; умение ладить с людьми, в том числе вращаться в свете; внимание к чтению книг и опыту старших; важность супружества. Неточное цитирование и перефразирование ряда текстов свидетельствуют о попытках Горохова примерить на себя образы лирических героев цитируемых стихотворений и поэм, однако оно может быть также результатом неточности или небрежности, вполне понятной в рукописи личного характера. Подробно освещено в рукописи отношение Горохова к проблеме чтения, к книге, к читающей женщине; здесь он также предстает как консерватор, с некоторым даже домостроевским оттенком. В целом, исходя из рассмотренного текста, Горохова можно охарактеризовать как внимательного, вдумчивого читателя, следящего за литературными новиками, творчески относящегося к прочитанному тексту.

Представляется, что необходимо дальнейшее исследование, комментирование и издание этого уникального в своем роде текста.

\section{Лuтература}

1. ОРКП НБ ТГУ. В-884.

2. Бойко В.П. Записки А.М. Горохова как источник по истории сибирского чиновничества в первой половине XIX в. (на основе архивных документов) // Вестн. Том. гос. ун-та. История. 2008. №3(4). C. 47-52.

3. Бойко В.П. Первый сибирский олигарх: предпринимательство и образ жизни чиновника и золотопромышленника Ф.А. Горохова // Человек - текст - эпоха: сб. науч. тр. и материалов. Вып. 4: Аналитические практики и перспективы современного источниковедения. Томск, 2011. C. 249-285.

4. Евтропов К.Н. История Троицкого кафедрального собора в Томске. Томск, 1904. 423 с.

5. Адрианов А.В. Томская старина // Город Томск. Томск, 1912. С. 101-183.

6. Свод учреждений государственных. Кн. 8. Учреждение орденов и других знаков отличия. Гл. 7. Статут имп. ордена св. равноапостольного князя Владимира. Отд. 1. Основные постановления и описание знаков ордена // Полн. собр. законов Российской империи. Собр. 3. Т. 9. № 6445 (1889 г.).

7. Статут ордена равноапостольного князя Владимира. СПб., 1801. 32 с.

8. Общий гербовник дворянских родов Всероссийской империи. СПб., б.г. Ч. 6, № 28.

9. О. Георгий (Крейдун Ю.А.). Алтайская духовная миссия в 1830-1919 гг.: структура и деятельность. М., 2008. 13 с.

10. Крейдун Ю.А. Деятельность архимандрита Макария на Алтае // История православия на Алтае: сб. статей. Барнаул / ред.-сост. Ю.А. Крейдун, К.Н. Метельницкий. Барнаул, 2001. C. $11-21$

11. Архив НБ ТГУ. Т. 19.

12. Державин Г.Р. Ода к моему соседу господину $\mathrm{N} / /$ Санкт-Петербургский вестник. 1780. №8. С. 108.

13. Державин Г.Р. Видение мурзы // Московский журнал. 1791. № 1. С. 8. 
14. Кантемир А.Д. Сатира I. На хулящих учения. К уму своему (фрагмент) // Кантемир А.Д. Собрание стихотворений. Л., 1956. С. 57.

15. Крылов И.А. Полное собрание сочинений: в 3 т. / ред. Д.Д. Благого. М.: Гос. изд-во худож. лит., 1946. Т. 3. Басни. Стихотворения. Письма. С. 263-266.

16. Сумароков П. «Битобе славную поэму сочинил...» // Русская эпиграмма второй половины XVII - начала XX в. М., 1975. С. 151.

17. Бытие сердца моего, или Стихотворения князя Ивана Михайловича Долгорукого. Ч. 3. М., 1818. $252 \mathrm{c}$.

18. Соколовский В.И. Мироздание. Опыт духовного стихотворения. Эпилог. Фрагмент // Опальные: Русские писатели открывают Кавказ: антология: в 3 т. Т. 2. Ставрополь, 2011. 768 с.

19. Соколовский В.И. Хеверь. Драматическая поэма (фрагмент) // Соколовский В.И. Хеверь. Драматическая поэма: в 3 ч. СПб., 1837. 244 с.

20. Грибоедов А.С. Горе от ума // Грибоедов А.С. Горе от ума. Фонвизин Д. Недоросль. Харьков, 2013.

21. Пуикин А.С. Поэту // Северные цветы на 1831 г. СПб., 1831. С. 3.

22. Пушкин В.Л. К лире // Поэты 1790-1810-х годов. Л., 1917. С. 656-657.

23. Лермонтов М.Ю. В альбом (из Байрона) // Отечественные записки. 1839. Т. 4, № 6. Отд. 3. С. 81.

24. Отрывки из монолога Фауста (перевод Э.И. Губерта) // Современник. 1837. № 2. C. $301-348$.

25. Губер Э.И. На кладбище (фрагмент) // Сочинения Э.И. Губера, изданные под редакцией А.Г. Тихменева. Т. 1. СПб., 1859. С. 53.

26. Якубович Л.А. За днями дни текут (полный текст) // Современник. 1838. № 4 (т. 12). C. $86-87$.

27. Шахова Е.Н. Три зари, или Слепец: повесть (фрагмент) // Шахова Е.Н. Стихотворения. СПб., 1839. С. 116-117.

\section{READER PRACTICE AND RECEPTION OF TEXT: TOMSK OFFICIAL OF THE 19TH} CENTURY ALEKSANDR M. GOROKHOV AND HIS EDIFICATION TO CHILDREN

Vestnik Tomskogo gosudarstvennogo universiteta. Filologiya - Tomsk State University Journal of Philology. 2017. 45. 150-170. DOI: 10.17223/19986645/45/11

Valeriya A. Esipova, Tomsk State University (Tomsk, Russian Federation). E-mail: esipova val@mail.ru

Keywords: history of literature, manuscripts, Siberia, Aleksandr M. Gorokhov.

The article is devoted to the text "Pledge or Moral Mirror", which was written by Tomsk official Aleksandr M. Gorokhov in the 1830s. The text is an edification to Gorokhov's children; it was not published ant it is currently stored as an author's manuscript in the Rare Books and Manuscripts Department of Tomsk State University Research Library (ORKP NB TGU). The paleographical description of the manuscript is given in the article; the records made by readers on the fields of the manuscript are examined; one of the readers was Agapit, the first bishop of Tomsk and Yenisei. The history of appearance of the manuscript in ORKP NB TGU is reconstructed.

The sources Gorokhov used were considered as well. The Bible took a special place among them: Gorokhov quoted both books of the Old and New Testament (Wisdom of Solomon, Five Books of Moses, the Epistles and others). Gorokhov was familiar with the works of Russian poets of the 18th century (G. Derzhavin, A. Kantemir, I. Krylov et al.). He very closely followed the development of contemporary Russian literature, especially poetry. There are numerous quotations from poems of A. Pushkin, M. Lermontov, A. Griboedov and others in the manuscript. Among the literary critics F. Bulgarin was closest to Gorokhov for his views; his opinion is repeatedly given in the manuscript.

Foreign literature attracted much less attention of Gorokhov. Perhaps the reason lies in his poor knowledge of foreign languages. In general, his acquaintance with foreign literature based most likely on the classical gymnasium program; and Russian literature was what he really loved and knew.

Subjects of quotations are connected with the problems of everyday life and experience that Gorokhov sought to convey to his children.

The methods of Gorokhov's work with the text are listed in the article. He rarely reproduced poem's full texts; the most common is combination of poetic fragments extracted from different works. At the same time, indications of author's names are quite rare. 
Also Gorokhov's manuscript allows identifying how soon newly published works arrived in Tomsk. The time gap between the publication of the magazine and its reading in Tomsk was about a year.

The article shows that the manuscript allows reconstructing the range of reading of the Tomsk official, his literary interests, his ideas about books and reading.

\section{References}

1. Rare Books and Manuscripts Department of Tomsk State University Research Library (ORKP NB TGU). V-884. (In Russian).

2. Boyko, V.P. (2008) Zapiski A.M. Gorokhova kak istochnik po istorii sibirskogo chinovnichestva v pervoy polovine XIX v. (na osnove arkhivnykh dokumentov) [Notes of A.M. Gorokhov as a source on the history of the Siberian officialdom in the first half of the 19th century (by archival documents)]. Vestnik Tomskogo gosudarstvennogo universiteta. Istoriya - Tomsk State University Journal of History. 3(4). pp. 47-52.

3. Boyko, V.P. (2011) Pervyy sibirskiy oligarkh: predprinimatel'stvo i obraz zhizni chinovnika i zolotopromyshlennika F.A. Gorokhova [The first Siberian oligarch: business and lifestyle of official and gold industry entrepreneur F.A. Gorokhov]. In: Dutchak, E.E. \& Zinov'ev, V.P. (eds) Chelovektekst - epokha [Man - text - era]. Vol. 4. Tomsk: Tomsk State University.

4. Evtropov, K.N. (1904) Istoriya Troitskogo kafedral'nogo sobora v Tomske [History of the Trinity Cathedral in Tomsk]. Tomsk: tip. Eparkhial'nogo bratstva.

5. Adrianov, A.V. (1912) Tomskaya starina [Tomsk antiquities]. In: Gorod Tomsk [The city of Tomsk]. Tomsk: izd-vo Sibirskogo tovarishchestva pechatnogo dela.

6. Russian Empire. (1891) Svod uchrezhdeniy gosudarstvennykh. Kn.8. Uchrezhdenie ordenov i drugikh znakov otlichiya. Gl. 7. Statut imp. ordena sv. ravnoapostol'nogo knyazya Vladimira. Otd. 1. Osnovnye postanovleniya i opisanie znakov ordena [List of public establishments. Book 8. Establishment of awards and other distinctions. Ch. 7. Statute of the Imperial Order of St. Vladimir. Pt. 1. Basic terms and the description of the Order signs]. Polnoe sobranie zakonov Rossiyskoy imperii. III:IX:6445.

7. Anon. (1782) Statut ordena ravnoapostol'nogo knyazya Vladimira [Statute of the Order of St. Vladimir]. St. Petersburg.

8. Anon. (n.d.) Obshchiy gerbovnik dvoryanskikh rodov Vserossiyskoy imperii. V 10 ch. [General book of heraldry of the Russian Empire. In 10 vols]. Vol. 6:28. St. Petersburg: Senatskaya tip.

9. P. Georgiy (Kreydun, Yu.A.). (2008) Altayskaya dukhovnaya missiya v 1830-1919 gg.: struktura i deyatel'nost' [Altai spiritual mission in 1830-1919: structure and activities]. Moscow: Izd-vo PSTGU.

10. Kreydun, Yu.A. (2001) Deyatel'nost' arkhimandrita Makariya na Altae [Activities of Archimandrite Makariy in the Altai]. In: Kreydun, Yu.A. \& Metel'nitskiy, K.N. (eds) Istoriya pravoslaviya na Altae [History of Orthodoxy in the Altai]. Barnaul: [s.n.].

11. Tomsk State University Research Library Archive. Vol. 19. (In Russian).

12. Derzhavin, G.R. (1780) Oda k moemu sosedu gospodinu N [Ode to my neighbor Mr. N]. Sankt-Peterburgskiy Vestnik. 8. pp. 108

13. Derzhavin, G.R. (1791) Videnie murzy [Vision of Murza]. Moskovskiy zhurnal. 1. pp. 8.

14. Kantemir, A.D. (1956) Satira I. Na khulyashchikh ucheniya. K umu svoemu (fragment) [Satire I. On those blaming doctrines. To my own mind (fragment)]. In: Kantemir, A.D. Sobranie stikhotvoreniy [Collected Poems]. Leningrad: Sovetskiy pisatel'.

15. Krylov, I.A. (1946) Polnoe sobranie sochineniy v 3 tomakh [Complete works in 3 volumes]. Vol. 3. Moscow: Gosudarstvennoe izdatel'stvo khudozhestvennoy literatury.

16. Sumarokov, S. (1975) "Bitobe slavnuyu poemu sochinil..." [“I composed a glorious poem for Bitoba"]. In: Ershov, L.F. et al. (eds) Russkaya epigramma vtoroy poloviny XVII - nachala XX v. [Russian epigram of the second half of the 17 th - early 20th centuries]. Leningrad: Sovetskiy pisatel'.

17. Dolgorukov, I.M. (1818) Bytie serdtsa moego, ili Stikhotvoreniya knyazya Ivana Mikhaylovicha Dolgorukogo [The being of my heart, or Poems of Prince Ivan Mikhailovich Dolgoruky]. Vol. 3. Moscow: Universitetskaya tip.

18. Sokolovskiy, V.I. (2011) Mirozdanie. Opyt dukhovnogo stikhotvoreniya. Epilog. Fragment [The Universe. The experience of spiritual poems. Epilogue. Fragment]. In: Shapovalov, V.A. \& Shtayn, K.E. (eds) Opal'nye: Russkie pisateli otkryvayut Kavkaz. Antologiya: V 3 t. [The disgraced: 
Russian writers discover the Caucasus. Anthology: in 3 vols]. Vol. 2. Stavropol: Stavropol State University.

19. Sokolovskiy, V.I. (1837) Khever'. Dramaticheskaya poema (fragment) [Heber. Dramatic Poem (excerpt)]. In: Sokolovskiy, V.I. Khever'. Dramaticheskaya poema $v$ trekh chastyakh [Heber. A dramatic poem in three parts]. St. Petersburg: V Tip. III Otd. Sobstv. E.I.V. Kantselyarii.

20. Griboedov, A.S. (2013) Gore ot uma [Woe from Wit]. In: Mezentseva, E.V. (ed.) Gore ot uma. Nedorosl' [Woe from Wit. The Minor]. Kharkov: Folio.

21. Pushkin, A.S. (1831) Poetu [To the Poet]. In: Del'vig, A.A. Severnye tsvety na $1831 \mathrm{~g}$. [Northern Flowers, 1831]. St. Petersburg: V Tip. Departamenta Vneshney Torgovli.

22. Pushkin, V.L. (1971) K lire [To the lyre]. In: Al'tshuller, M.G. (ed.) Poety 1790-1810-kh godov [Poets of the 1790s-1810s]. Leningrad: Sovetskiy pisatel.

23. Lermontov, M.Yu. (1839) V al'bom (iz Bayrona) [For the album (from Byron)]. Otechestvennye zapiski. IV:6:III. pp. 81.

24. Sovremennik. (1837) Otryvki iz monologa Fausta [Excerpts from the monologue of Faust]. Translated from German by E.I. Guber. Sovremennik. 2. pp. 301-348.

25. Guber, E.I. (1859) Na kladbishche (fragment) [At the cemetery (fragment)]. In: Tikhmenev, A.G. (ed.) Sochineniya E.I. Gubera [Works by E.I. Guber]. Vol. 1. St. Petersburg: izd. A Smirdina.

26. Yakubovich, L.A. (1838) Za dnyami dni tekut (polnyy tekst) [Days by days flow by (full text)]. Sovremennik. 4:XII. pp. 86-87.

27. Shakhova, E.N. (1839) Tri zari ili Slepets. Povest' (fragment) [Three dawns or the Blind. A tale (fragment)]. In: Shakhova, E.N. Stikhotvoreniya [Poems]. St. Petersburg: Academy of Sciences. 